\title{
Study of The Effect of TiO2 Addition On The Crystalline Phases, Structure and Chemical Durability of a Nuclear Glass Ceramic
}

\section{Rafika SOUAG ( $\nabla$ r.souag@univ-boumerdes.dz)}

University of Boumerdes: Universite M'Hamed Bougara Boumerdes https://orcid.org/0000-0002-74141434

Nour elhayet KAMEL

Nuclear Research Center

Dalila Moudir

Nuclear Research Center

Yasmina MOUHEB

Nuclear Research Center

Fayrouz Aouchiche

Nuclear Research Center

\section{Research Article}

Keywords: Nuclear glass ceramics, TiO2, XRD, SEM, Chemical durability

Posted Date: September 14th, 2021

DOI: https://doi.org/10.21203/rs.3.rs-861278/v1

License: (c) (1) This work is licensed under a Creative Commons Attribution 4.0 International License.

Read Full License 


\title{
Study of the effect of $\mathrm{TiO}_{2}$ addition on the crystalline phases, structure and chemical durability of a nuclear glass ceramic
}

Rafika Souag ${ }^{1, *}$, Nour elhayet Kamel $^{2}$, Dalila Moudir ${ }^{2}$, Yasmina Mouheb ${ }^{2}$, Fayrouz Aouchiche $^{2}$

${ }^{1}$ Research Unit, Materials, Processes and Environment (URMPE), University of Boumerdes, Algeria

${ }^{2}$ Environment, Safety and Radioactive Waste Division, Nuclear Research Centre of Algiers, 2. Bd frantz Fanon, BP : 399, Alger-RP9, Algiers, Algeria

*Corresponding author, E-mail address: r.souag@univ-boumerdes.dz

\begin{abstract}
This study focused on the effect of $\mathrm{TiO}_{2}$ addition on the crystallines phases' formation, structure and chemical durability of a nuclear glass ceramic constituted by an aluminosilicate glass in the system: $\mathrm{SiO}_{2}-\mathrm{Al}_{2} \mathrm{O}_{3}-\mathrm{CaO}-\mathrm{MgO}-\mathrm{ZrO}_{2}-\mathrm{TiO}_{2}$. The materials with four contents of $\mathrm{TiO}_{2}$, ranging from 4.11 to $7.11 \mathrm{wt} . \%$, are synthesized by a discontinuous method,. For the whole of materials, X-ray diffraction analysis allow identifying an aluminosilicate belonging to pyroxenes silicates family as a main phase, powelite and calzirtite. Both SEM and DTAanalyses confirmed these results. The materials FTIR analysis reveals the glass ceramics complex chemical composition. MCC1 and MCC2 tests, performed on selected glass ceramic materials, indicate that the materials with 4.11 and $5.11 \mathrm{wt} . \% \mathrm{TiO}_{2}$ are the most durable against $\mathrm{Si}, \mathrm{Al}, \mathrm{Mg}$ and $\mathrm{Ce}$ elements release, in $\mathrm{MCC} 2$ test; The results make conclusions valuable on the selection of such glass ceramics as candidate for the disposal of high-level waste.
\end{abstract}

Keywords: Nuclear glass ceramics; $\mathrm{TiO}_{2}$; XRD; SEM; Chemical durability 


\section{Introduction}

The storage and disposal of radioactive waste (RW) is a difficult task. It necessitates meticulous control. One of the RW disposal principles is to follow the waste through all stages of its life: packaging, storage, disposal, and monitoring until its radioactivity is comparable to natural background radiation [1]. A multitude of sequestration materials have been studied, among glasses, minerals, and glass-ceramic matrices.

The main works dealing with this last kind of materials concern the sequestration of the whole of radionuclides present in a liquid waste solution [2,3].

Nevertheless, because of both their high chemical durability and high ability to incorporate specific radionuclides, several ceramic matrices such as zirconates, titanates and phosphates have been proposed for the immobilization of long-lived radionuclides such as minor actinides [4-6].

The ceramics elaboration processes are difficult to implement, and many glass-ceramics are also under study. They consist of crystals homogeneously distributed in a glass matrix, and exhibit increased performances. Both glass technology and the interesting confinement properties of crystalline ceramic phases will support research on glass-ceramics (noted: GC) matrices for RW sequestration. It have been demonstrated that different nucleating agents added to a chosen parent glass has an important role on the crystallization processes and on the physico-mechanical properties of a given GC [7, 8]. The effect of many nucleating agents such as $\mathrm{ZrO}_{2}$ and $\mathrm{TiO}_{2}$ on the crystallization, microstructure and durability properties of the prepared GC was reported in the literature [9-11].

Despite the significance of $\mathrm{TiO}_{2}$ 's role in the structure of silicate glasses, few studies have been conducted to date [12]. $\mathrm{TiO}_{2}$ is known to be quite soluble in silicate melts. It decreases the melt glass viscosity [7]. $\mathrm{TiO}_{2}$ addition influences the crystalline phase nature and the microstructure formed in the GC materials, and their physico-mechanical properties [13, 14]. Zhou et al. [15] noted that $\mathrm{TiO}_{2}$ is often used to facilitate nucleation in silicate glass-ceramics systems. The effect of $\mathrm{TiO}_{2}$ content on the crystalline phases, structure, and aqueous dissolution rate of iron phosphate based glass ceramic waste forms was studied in depth by $\mathrm{Fu}$ Wang et al. [16].

In this study, we have synthesized a $\mathrm{TiO}_{2}$-rich $\mathrm{GC}$ by a discontinuous method, consisting in a double melting at $1350{ }^{\circ} \mathrm{C}$, followed by both a crystallization and crystal-growth, treatments at 564 and $1010{ }^{\circ} \mathrm{C}$, respectively. In order to study the influence of the effect of $\mathrm{TiO}_{2}$ addition 
on the crystalline phases, structure and chemical durability of a nuclear GC,constituted by an aluminosilicate glass in the system: $\mathrm{SiO}_{2}-\mathrm{Al}_{2} \mathrm{O}_{3}-\mathrm{CaO}-\mathrm{MgO}-\mathrm{ZrO}_{2}-\mathrm{TiO}_{2}$, the materialswith four contents of $\mathrm{TiO}_{2}$, ranging from 4.11 to $7.11 \mathrm{wt} . \%$, are synthesized. The materials densities are measured.The materials are characterized by many spectroscopic techniques (X-ray diffraction (XRD), scanning electronic microscopy (SEM), differential thermal analysis (DTA) and Fourier Transform Infrared Spectroscopy (FTIR)). In addition, chemical durability testing was carried out using the standard MCC-1 and MCC- 2 static leach test methods at 25 ${ }^{\circ} \mathrm{C}$ and $90{ }^{\circ} \mathrm{C}$, respectively.

\section{Experimental}

The GC chemical compositions are inspired from previous research studies $[17,18]$. The samples are prepared with the following $\mathrm{TiO}_{2}$ contents: 4.11, 5.11, 6.11 and 7.11wt. \% (Table 1). The corresponding glass ceramics are noted: $\mathrm{GC} 1, \mathrm{GC} 2, \mathrm{GC} 3, \mathrm{GC} 4$, respectively.

The employed commercial reagents are: $\mathrm{Al}_{2} \mathrm{O}_{3}$ (Fluka), $\mathrm{B}_{2} \mathrm{O}_{3}$ (Purity $\geq 99 \%$ ), $\mathrm{CaO}$ (Merck, $\geq$ $97 \%$ ), $\mathrm{CeO}_{2}$ (Aldrich, $99.999 \%$ ), $\mathrm{CrO}_{3}$ (Merck, $\geq 99 \%$ ), $\mathrm{Fe}_{2} \mathrm{O}_{3}$ (Merck, $\geq 99 \%$ ), $\mathrm{K}_{2} \mathrm{CO}_{3}$ (Merck, $\geq 99 \%$ ), $\mathrm{Li}_{2} \mathrm{O}$ (Merck, $\geq 99 \%$ ), $\mathrm{MgO}$ (Flucka, $\geq 97 \%$ ), $\mathrm{MnO}_{2}$ (Merck), $\mathrm{MoO}_{3}$ (Merck, $\geq 99.5 \%$ ), $\mathrm{Nd}_{2} \mathrm{O}_{3}$ (Fluka, $\geq 99.9 \%$ ), $\mathrm{P}_{2} \mathrm{O}_{5}$ (Merck, $\geq 98$ \%), $\operatorname{Pr}_{6} \mathrm{O}_{11}$ (Merck, $\geq 99 \%$ ), $\mathrm{SiO}_{2}$ (Prolabo), $\mathrm{Ta}_{2} \mathrm{O}_{5}$ (Merck, $\geq 99 \%$ ), $\mathrm{TiO}_{2}$ (Merck, $\geq 99 \%$ ), $\mathrm{V}_{2} \mathrm{O}_{5}$ (Labosi), $\mathrm{WO}_{3}$ (Merck), $\mathrm{Y}_{2} \mathrm{O}_{3}$ (Merck, $\geq 99 \%$ ), $\mathrm{Yb}_{2} \mathrm{O}_{3}$ (Aldrich, $99.9 \%$ ), $\mathrm{ZrO}_{2}$ (Aldrich, $99 \%$ ). REE elements' oxides are dried over night at $1000{ }^{\circ} \mathrm{C}$, and the other oxides at $400{ }^{\circ} \mathrm{C}$, for the same time. $\mathrm{BaO}, \mathrm{Er}_{2} \mathrm{O}_{3}, \mathrm{La}_{2} \mathrm{O}_{3}$ and $\mathrm{NiO}$ are prepared by calcination at $450{ }^{\circ} \mathrm{C}$ of $\mathrm{BaNO}_{3}$ (Fluka, $99.6 \%$ ), $\mathrm{ErN}_{3} \mathrm{O}_{9} \cdot 5 \mathrm{H}_{2} \mathrm{O}$ (Acros Organics, $99.9 \%$ ), $\mathrm{La}\left(\mathrm{NO}_{3}\right)_{3} \cdot 6 \mathrm{H}_{2} \mathrm{O}$ (Fluka, $99.99 \%$ ), and $\mathrm{Ni}\left(\mathrm{NO}_{3}\right)_{2} \cdot 6 \mathrm{H}_{2} \mathrm{O}$ (Fluka, $99.6 \%$ ), respectively.

The GC synthesis is carried out by a double melting at $1350{ }^{\circ} \mathrm{C}$. This is necessary to ensure a complete homogenization of the oxides mixture, and thus isotropic properties of the final products. The melts are poured in a graphite cylindrical mold to obtain pellets. The nucleation step is carried out at a Tn temperature during $2 \mathrm{~h}$, such that: $\mathrm{Tn}=\mathrm{Tg}+30^{\circ} \mathrm{C}$, with $\mathrm{Tg}$ is the glass transition temperature. The crystal growth treatment (Tc) is performed at $1010{ }^{\circ} \mathrm{C}$ for 3 $\mathrm{h}$, for the whole of materials. They are finally cooled to ambient air.Both $\mathrm{Tg}$ and $\mathrm{Tc}$ are deducted from the DTA (differential thermal analysis) diagram of the parent glass. The details of DTA diagrams are given in a previous study [17]. 
Table 1. Chemical composition of the synthesized GC materials

\begin{tabular}{|c|c|c|c|c|}
\hline \multirow{2}{*}{$\begin{array}{l}\text { Oxides } \\
\text { (wt.\%) }\end{array}$} & \multicolumn{4}{|c|}{ Content (\%) } \\
\hline & GC1 & GC2 & GC3 & GC4 \\
\hline $\mathrm{TiO}_{2}$ & 4.110 & 5.110 & 6.110 & 7.110 \\
\hline $\mathrm{Al}_{2} \mathrm{O}_{3}$ & 13.040 & 13.040 & 13.040 & 13.040 \\
\hline $\mathrm{B}_{2} \mathrm{O}_{2}$ & 0.800 & 0.800 & 0.800 & 0.800 \\
\hline $\mathrm{BaO}$ & 1.600 & 1.600 & 1.600 & 1.600 \\
\hline $\mathrm{CaO}$ & 9.000 & 9.000 & 9.000 & 9.000 \\
\hline $\mathrm{CeO}_{2}$ & 3.010 & 3.010 & 3.010 & 3.010 \\
\hline $\mathrm{CrO}_{3}$ & 0.400 & 0.400 & 0.400 & 0.400 \\
\hline $\mathrm{Er}_{2} \mathrm{O}_{3}$ & 1.310 & 1.310 & 1.310 & 1.310 \\
\hline $\mathrm{Fe}_{2} \mathrm{O}_{3}$ & 1.310 & 1.310 & 1.310 & 1.310 \\
\hline $\mathrm{K} 2 \mathrm{O}$ & 0.670 & 0.670 & 0.670 & 0.670 \\
\hline $\mathrm{La}_{2} \mathrm{O}_{3}$ & 0.500 & 0.500 & 0.500 & 0.500 \\
\hline $\mathrm{Li}_{2} \mathrm{O}$ & 4.220 & 4.220 & 4.220 & 4.220 \\
\hline $\mathrm{MgO}$ & 3.500 & 3.500 & 3.500 & 3.500 \\
\hline $\mathrm{MnO}_{2}$ & 0.200 & 0.200 & 0.200 & 0.200 \\
\hline $\mathrm{MoO}_{3}$ & 2.810 & 2.810 & 2.810 & 2.810 \\
\hline $\mathrm{Nd}_{2} \mathrm{O}_{3}$ & 1.200 & 1.200 & 1.200 & 1.200 \\
\hline $\mathrm{NiO}$ & 0.600 & 0.600 & 0.600 & 0.600 \\
\hline $\mathrm{P}_{2} \mathrm{O}_{5}$ & 0.400 & 0.400 & 0.400 & 0.400 \\
\hline $\operatorname{Pr}_{6} \mathrm{O}_{11}$ & 0.100 & 0.100 & 0.100 & 0.100 \\
\hline $\mathrm{SiO}_{2}$ & 49.02 & 48.020 & 47.02 & 46.02 \\
\hline $\mathrm{Ta}_{2} \mathrm{O}_{5}$ & 0.200 & 0.200 & 0.200 & 0.200 \\
\hline $\mathrm{V}_{2} \mathrm{O}_{5}$ & 0.100 & 0.100 & 0.100 & 0.100 \\
\hline $\mathrm{WO}_{3}$ & 0.800 & 0.800 & 0.800 & 0.800 \\
\hline $\mathrm{Y}_{2} \mathrm{O}_{3}$ & 0.500 & 0.500 & 0.500 & 0.500 \\
\hline $\mathrm{Yb}_{2} \mathrm{O}_{3}$ & 0.100 & 0.100 & 0.100 & 0.100 \\
\hline $\mathrm{ZrO}_{2}$ & 0.500 & 0.500 & 0.500 & 0.500 \\
\hline Total & 100.000 & 100.000 & 100.000 & 100.000 \\
\hline
\end{tabular}

The materials Archimedes density is measured by pycnometer with water as a wetting liquid. The XRD analysis is carried out using a PANALytical X'Pert Pro diffractometer equipped with a copper anticathode, with $\mathrm{K} \alpha 1=1.5418 \AA$. The analyses are performed with a voltage of 
$40 \mathrm{kV}$ and a current intensity of $40 \mathrm{~mA}$, for $2 \theta$ ranging between 3 and $80^{\circ}$. The ceramics phase identification is performed using a Philips X'Pert High Score Plus software, version 4.1 [19]. The materials microstructure is revealed by SEM microscopy observations, conducted on a Philips XL30 microscope.

The DTA analysis of GCs with different $\mathrm{TiO}_{2}$ contents is performed using a NETZSCH STA 409 PC device on powders, for which 11 to $25 \mathrm{mg}$ of powder in an alumina crucible, is heated in a $20 \% \mathrm{~N}_{2}-80 \% \mathrm{O}_{2}$ atmosphere at $15^{\circ} \mathrm{C} / \mathrm{min}$ up to $1050^{\circ} \mathrm{C}$. The analyzes are carried out in the temperature range from 20 to $1450{ }^{\circ} \mathrm{C}$.

The FTIR spectra of the samples are recorded from 4000 to $400 \mathrm{~cm}^{-1}$ (wave numbers)by a standard $\mathrm{KBr}$ pellet method using a NICOLET 380 spectrometer. The pellets are prepared by mixing about 1-2 mg of glass powder with 100-200 mg of anhydrous $\mathrm{KBr}$. The resolution of the device is $4 \mathrm{~cm}^{-1}$. The spectra data processing is performed by the OMNIC software [20].

Two normalized IAEA static leach tests, MCC1 and MCC2, are performed on selected GC materials among the different $\mathrm{TiO}_{2}$ contents [21]. The Surface/Volume ratio must be constant throughout the test and equal to 1/10. The GC materials cylindrical pellets are immersed in bidistilled water, in dark glass bottles. MCC1 leach test is performed at ambient temperature (25 $\pm 1)^{\circ} \mathrm{C}$ in opened bottles, and MCC2 leach test in closed bottles, left in an oven heated at (90 $\pm 1)^{\circ} \mathrm{C}$. For both tests, water samplings are performed at: 1, 3, 7, 14, 21, 36, 42 and 96 days. The materials kinetic of dissolution was performed following: $\mathrm{Si}, \mathrm{Al}, \mathrm{Mg}$ and $\mathrm{Ce}$ (actinide surrogate), elements dissolution in the leachates. The speed of dissolution is assessed by a PANALytical Magi-xPro wavelength dispersive X-ray fluorescence (WDXRF) spectrometer. The calibration curves of $\mathrm{Si}, \mathrm{Al}, \mathrm{Mg}$ and Ce elements are made from ICP/DCP standards of $1000 \pm 4 \mathrm{mg} / \mathrm{L}$ for each element. The concentrations are all between 20 and $500 \mathrm{mg} / \mathrm{L}$. All XRF analyses are performed on Myllar films of spectroscopic grade, on which $30 \mu \mathrm{L}$ of each elemental standard solution is dropped.

The leachates concentrations $\mathrm{Ci}\left(\mathrm{g} / \mathrm{cm}^{3}\right)$ for each i element $(\mathrm{Si}, \mathrm{Al}, \mathrm{Mg}$ or $\mathrm{Ce})$ were deduced from WDXRF spectrometric calibration curves. The i element mass loss, NLi $\left(\mathrm{g} / \mathrm{cm}^{2}\right)$, for each range of time, taken from the starting time of test, was calculated using the formula:

$$
N L i=C i . V o / S o . F i
$$

where $\mathrm{V}$ : is the leaching mixture total volume $\left(\mathrm{cm}^{3}\right), \mathrm{S}$ is the initial sample surface effectively in contact with the leachate $\left(\mathrm{cm}^{2}\right)$, and $\mathrm{Fi}$ is the $\mathrm{i}$ element weight fraction of the GC materials 
pellet. $\mathrm{S}\left(\mathrm{cm}^{2}\right)$ is assumed to be constant during the tests, and $\mathrm{Ci}$, the initial elemental concentrations in the leachate negligible.

Each i element mean normalized dissolution rate $\mathrm{RLi}\left(\mathrm{g} / \mathrm{cm}^{2} \mathrm{~d}^{-1}\right)$ was deduced from the mathematical relation number (2). The Origin 8.5 Graph software was used for mathematical calculations.

$$
R L i=(C i * V) /(f i * S * \Delta t)
$$

where: $\Delta \mathrm{t}$ : is the test duration in days (d).

\section{Results and Discussion}

\subsection{Materials morphologies and densities}

The 7.11wt.\% $\mathrm{TiO}_{2}$ content GC synthesis was not successful, this GC exhibits a very strong crystallization in the mass during melting.

For the other $\mathrm{TiO}_{2}$ contents in the $\mathrm{GC}$, after the crystallization step, the transparent glassy samples color turns into an opaque dark gray color with brown reflections (Fig. 1).On the cross-sections of the glass-ceramics, one can observe with the naked eye a relatively clear difference in appearance between the surface and the bulk of the samples, which has a darker gray color in the materials bulk compared to the surface color.

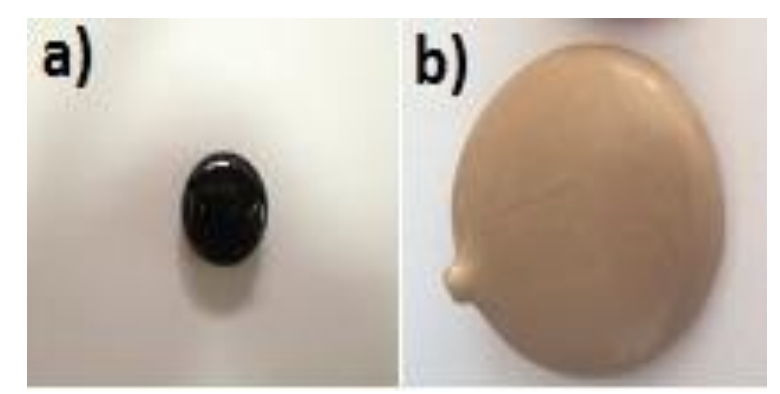

Fig. 1. General appearance of synthetic GC materials, (a) Parent glass after fusion and (b) Parent glass after crystallization

The density of the obtained GCs with different contents of $\mathrm{TiO}_{2}$ is measured by the Archimedes method. The results are given in Table 2.

The GC density varies randomly with the $\mathrm{TiO}_{2}$ content. In general, it is between 2.8913 and $2.9618 \mathrm{~g} / \mathrm{cm}^{3}$, for $\mathrm{GC}^{\prime} \mathrm{TiO}_{2}$ contents ranging from 4.11 to $6.11 \%$. Overall, the results are close to other nuclear GC materials densities reported in the literature. GC with diopside ( $\mathrm{PNC}$ 62) and diopside (PNC 718) mineral phases, synthesized in a $\mathrm{TiO}_{2}$-rich borosilicate 
glass melted at $\mathrm{T}_{\mathrm{f}}=1185^{\circ} \mathrm{C}$ and $1120^{\circ} \mathrm{C}$, have densities of 3.01 and $2.94 \mathrm{~g} / \mathrm{cm}^{3}$, respectively. Other GC materials with sphenes minerals formed in their structure have a density between 2.78 and $2.95 \mathrm{~g} / \mathrm{cm}^{3}$ [22]. A. Quintas et al. [23] have synthesized a GC from a Lu-aluminoborosilicate glass, for high-level waste (HLW) sequestration, at a melting temperature of $1350^{\circ} \mathrm{C}$ and a crystallization step at $\mathrm{Tc}=934^{\circ} \mathrm{C}$. They report a density of $2.946 \mathrm{~g} / \mathrm{cm}^{3}$. This value is close to our experimental values.

Table 2. The GC Archimedes density $\left(\boldsymbol{\rho}_{A}\right)$ as a function of $\mathrm{TiO}_{2}$ content

\begin{tabular}{ccccc}
\hline GCs & GC1 & GC2 & GC3 & GC4 \\
\hline $\mathbf{T i O}_{\mathbf{2}}(\boldsymbol{\%})$ & 4.11 & 5.11 & 6.11 & 7.11 \\
& & & & \\
$\boldsymbol{\rho}_{\boldsymbol{A}}\left(\mathbf{g} / \mathbf{c m}^{\mathbf{3}}\right)$ & 2.9618 & 2.8913 & 2.9192 & ---- \\
\hline
\end{tabular}

T. Wakihara et al. [24] studied the effect of $\mathrm{TiO}_{2}$ content in a glass in the system Y-Si-Al-O-N melted at $1700{ }^{\circ} \mathrm{C}$, and concluded of a random variation of density with the $\mathrm{TiO}_{2}$ content. All the reported values are over $3.5 \mathrm{~g} / \mathrm{cm}^{3}$, and are higher than the GC densities of the present GC materials. Yttrium (Y) of atomic mass 88.90 amu being the preponderant dopant in the studied glass contributed to increase the material density.

\subsection{Microstructural characterization}

The diffractograms of the studied GCs are gathered in fig. 2. The phases' identification of the $\mathrm{GC}$ at different $\mathrm{TiO}_{2}$ contents is given in table 3.

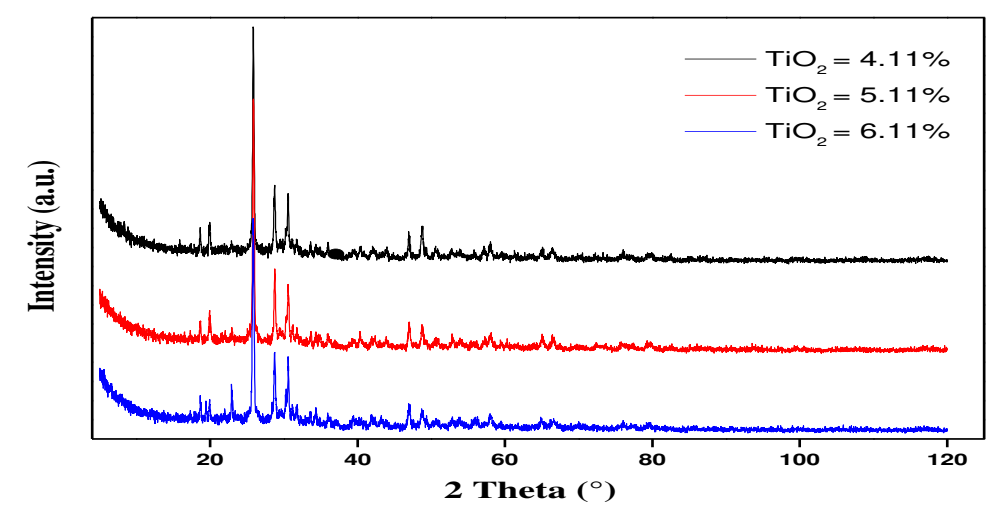

Fig. 2. XRD diffractogramms of glass-ceramics with different contents of $\mathrm{TiO}_{2}$ 
Except for GC7, for the whole of materials, the main formed crystalline phase is an aluminosilicate, of the pyroxene family $\left(\mathrm{Si}_{2} \mathrm{O}_{6}\right)$, which is known to be a containment barrier against radionuclide dissipation. Its crystal structure is orthorhombic or monoclinic. Its content in the $\mathrm{GC}$ is more than $70 \%$. For 4.11 and 5.11 wt.\% $\mathrm{TiO}_{2} \mathrm{GCs}$, the $\mathrm{XRD}$ semiquantitative analysis gave: $77 \%$ of $\mathrm{Mg}_{0.6} \mathrm{Al}_{1.2} \mathrm{Si}_{1.8} \mathrm{O}_{6}$ pyroxene phase (JCPDS N $01-075$ 1568), $10 \%$ of $\mathrm{CaMoO}_{4}$ (JCPDS N $\mathrm{N}^{\circ}$ 01-085-0585) and $13 \%$ of $\mathrm{Ca}_{2} \mathrm{Zr}_{5} \mathrm{Ti}_{2} \mathrm{O}_{16}$ calzirtite phase (JCPDS $\mathrm{N}^{\circ}$ 01-077-1131). The presence of these phases means that ions in the glass matrix are moving and reacting [25]. The formation of calzirtite, is favored by the increase in $\mathrm{TiO}_{2}$ content in the GC materials. It increases to $25 \%$ for the 6.11 wt. $\% \mathrm{TiO}_{2}$ content GC. One can conclude that for the whole of $\mathrm{TiO}_{2}$ contents in the materials, (4.11 to $6.11 \mathrm{wt} . \%$ ), the GC microstructure contains self-irradiation highly resistant crystals, which are able to confine radioactive waste elements [26].

One can note that calzirtite was identified by HJ Rossell [27] in a similar glass system, CaO$\mathrm{ZrO}_{2}-\mathrm{TiO}_{2}$ system, melted at temperatures below $1370{ }^{\circ} \mathrm{C}$. Yu-Han and $\mathrm{Wu}$ Taiwan [28] have also investigated a comparable GC material: a Ti-Zr-rich Li-aluminosilicate, and identify calzirtite minerals. These last authors observed the formation of $\beta$-quartz phase at a low crystallization temperature $\mathrm{Tc}=750{ }^{\circ} \mathrm{C}$, which transforms in a pyroxene-type $\beta$-spodumene at $880{ }^{\circ} \mathrm{C}$. L.S. Bozadzhiev et al. [29] also observe an isomorph $(\mathrm{Ca}, \mathrm{Na})(\mathrm{Mg}, \mathrm{Fe}, \mathrm{Al})(\mathrm{Si}, \mathrm{Al})_{2} \mathrm{O}_{6}$ pyroxene phase which forms a solid solution with radioactive waste elements as : $\mathrm{Sr}, \mathrm{Ba}, \mathrm{Zr}$, $\mathrm{Y}, \mathrm{Ga}, \mathrm{Ce}, \mathrm{Pr}, \mathrm{Nd}, \mathrm{Gd}$, etc. These phases are obtained from a basanite GC containing radionuclides surrogates from I-VIII group (5-15 wt.\%). The materials were melted at 1450 ${ }^{\circ} \mathrm{C}$, and crystallized at $950{ }^{\circ} \mathrm{C}$. M. Chavoutier et al.[30] have synthesized Ti-rich GC materials in the system $\mathrm{SiO}_{2}, \mathrm{Li}_{2} \mathrm{CO}_{3}, \mathrm{Al}_{2} \mathrm{O}_{3}, \mathrm{ZrO}_{2}$ and $\mathrm{TiO}_{2}$, with a double-melting at $1450{ }^{\circ} \mathrm{C}$. They observe the spodumene phase $\left(\mathrm{Si}_{2} \mathrm{O}_{6}\right)$ germination for a Tc temperature above $1105^{\circ} \mathrm{C}$. From all these results, it appears that a crystallization heat treatment at a temperature higher than $950{ }^{\circ} \mathrm{C}$, in systems comparable to the one we used, promotes the formation of an aluminosilicate, of the pyroxene family. This is the case for the GCs currently studied, which crystallize at $1010^{\circ} \mathrm{C}$. 
Table 3. The GCs' phase identification for different contents of $\mathrm{TiO}_{2}$

\begin{tabular}{|c|c|c|c|c|}
\hline \multirow{2}{*}{$\begin{array}{l}\mathrm{GC} \\
\mathrm{GC1}\end{array}$} & \multirow{2}{*}{$\begin{array}{l}\mathrm{TiO}_{2} \\
\text { (wt.\%) } \\
4.1\end{array}$} & \multicolumn{2}{|c|}{ Semi-quantitative composition (\%) } & \multirow{2}{*}{$\begin{array}{c}\text { JCPDS data [18] } \\
01-075-1568\end{array}$} \\
\hline & & $77 \%$ & $\mathrm{Mg}_{0.6} \mathrm{Al}_{1.2} \mathrm{Si}_{1.8} \mathrm{O}_{6}$ & \\
\hline & & $11 \%$ & $\mathrm{CaMoO}_{4}$ & $01-085-0585$ \\
\hline & & $10 \%$ & $\mathrm{Li}_{2} \mathrm{Fe}_{5} \mathrm{Cr}_{5} \mathrm{O}_{16}$ & $01-073-0213$ \\
\hline & & $1 \%$ & $\mathrm{KFeO}_{2}$ & $01-083-2153$ \\
\hline \multirow[t]{4}{*}{$\mathrm{GC} 2$} & 5.1 & $77 \%$ & $\mathrm{Mg}_{0.6} \mathrm{Al}_{1.2} \mathrm{Si}_{1.8} \mathrm{O}_{6}$ & $01-075-1568$ \\
\hline & & $9 \%$ & $\mathrm{CaMoO}_{4}$ & $01-085-0585$ \\
\hline & & $11 \%$ & $\mathrm{Ca}_{2} \mathrm{Zr}_{5} \mathrm{Ti}_{2} \mathrm{O}_{16}$ & $01-077-1131$ \\
\hline & & $3 \%$ & $\operatorname{Pr}_{15} \mathrm{Ni}_{7} \mathrm{Si}_{10}$ & $01-077-1647$ \\
\hline \multirow[t]{4}{*}{ GC3 } & 6.1 & $70 \%$ & $\mathrm{Mg}_{0.6} \mathrm{Al}_{1.2} \mathrm{Si}_{1.8} \mathrm{O}_{6}$ & $01-073-2338$ \\
\hline & & $15 \%$ & $\mathrm{CaMoO}_{4}$ & $01-085-0585$ \\
\hline & & $12 \%$ & $\mathrm{Ca}_{2} \mathrm{Zr}_{5} \mathrm{Ti}_{2} \mathrm{O}_{16}$ & $01-077-1131$ \\
\hline & & $3 \%$ & $\mathrm{Ba}_{0.905} \mathrm{Ca}_{0.08}\left(\mathrm{TiO}_{3}\right)$ & $01-082-2234$ \\
\hline $\mathrm{GC} 4$ & 7.1 & --- & & --- \\
\hline
\end{tabular}

The SEM observations of the GC specimen microstructure were carried out on the samples cross sections. The SEM micrographs are depicted on Fig. 3. Such micrographs allowed us to observe both types of phases: crystalline and glassy ones, and confirm the nature of the crystalline phases identified by XRD analysis. The samples are fully ceramized. The dark prisms are characteristics features of pyroxene phase's germination in most samples. This form often appears in the monoclinic structure. Some authors describe these prisms as "stocky" forms [28, 31].The crystals of calzirite are dipyramidal but light in color. They appear as small piles on the micrographs contrast [26]. The phases appearing in clear platelets are tetragonal powellite crystals [32]. 

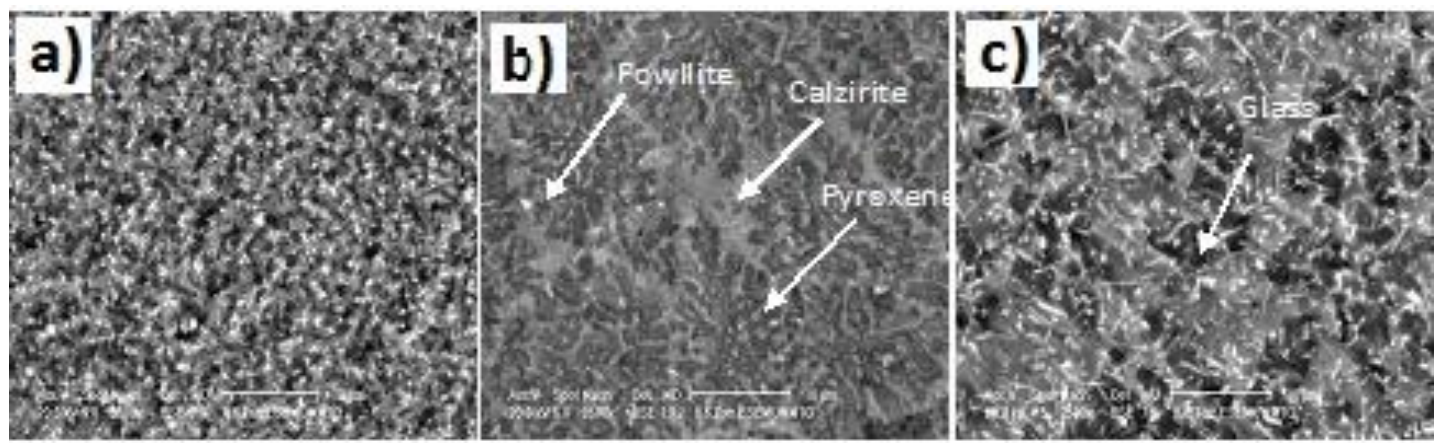

Fig. 3. SEM micrographs of the $\mathrm{GC}$ materials with different $\mathrm{TiO}_{2}$ contents. a) $4.11 \mathrm{wt}$. $\% \mathrm{TiO}_{2-}$ GC, b) $5.11 \mathrm{wt} . \% \mathrm{TiO}_{2}$-GC. c) $6.11 \mathrm{wt} . \% \mathrm{TiO}_{2}-\mathrm{GC}$

Fig. 4 shows the DTA curve of the GCs with different $\mathrm{TiO}_{2}$ contents. For the GC with $5.11 \mathrm{wt} . \% \mathrm{TiO}_{2}$, the parent glass crystallization temperature appears around $563{ }^{\circ} \mathrm{C}$. An allotropic transformation of the calzirtite $\left(\mathrm{Ca}_{2} \mathrm{Zr}_{5} \mathrm{Ti}_{2} \mathrm{O}_{16}\right)$ crystal from monoclinic to tetragonal is revealed around $990{ }^{\circ} \mathrm{C}$ for the three $\mathrm{GC}$ at different $\mathrm{TiO}_{2}$ contents. It should be noted that the calzirtite crystal, $\mathrm{Ca}_{2} \mathrm{Zr}_{5} \mathrm{Ti}_{2} \mathrm{O}_{16}$, is often associated with that of zirconolite in magma-type rocks, and shows slight variations in their composition, especially the substitution type with respect to lanthanides and actinides, found in trace amounts in these rocks [33]. An allotropic transformation around $1090{ }^{\circ} \mathrm{C}$ and $1150{ }^{\circ} \mathrm{C}$, attributable to the pyroxene and wollastonite crystal (of the pyroxenoids family) respectively, is observed for the three GCs at different $\mathrm{TiO}_{2}$ contents. M. Chavoutier et al [30] report the phase transformation of spodumene, a compound of the same family as pyroxene, around $1050{ }^{\circ} \mathrm{C}$, in a $\mathrm{GC}$ made from a $\mathrm{Li}_{2} \mathrm{O}$ $\mathrm{Al}_{2} \mathrm{O}_{3}-\mathrm{SiO}_{2}$ type glass. Indeed, $\mathrm{H}$. Khedim et al [10] show a transformation, attributed to the formation of pseudo wollastonite at $1170{ }^{\circ} \mathrm{C}$. The ternary phase diagram of: $\mathrm{SiO}_{2}-\mathrm{Al}_{2} \mathrm{O}_{3}-\mathrm{CaO}$ shows well the range of existence of these phases. We note that the allotropic transformations of $\mathrm{CaMoO}_{4}\left(630\right.$ and 690,810 and $880{ }^{\circ} \mathrm{C}$ ) are undetectable on the DTA diagrams, because the content of this molybdate is very low and therefore the transformations are not apparent on the spectra. Finally, no melting phenomenon is observed up to $1450^{\circ} \mathrm{C}$.

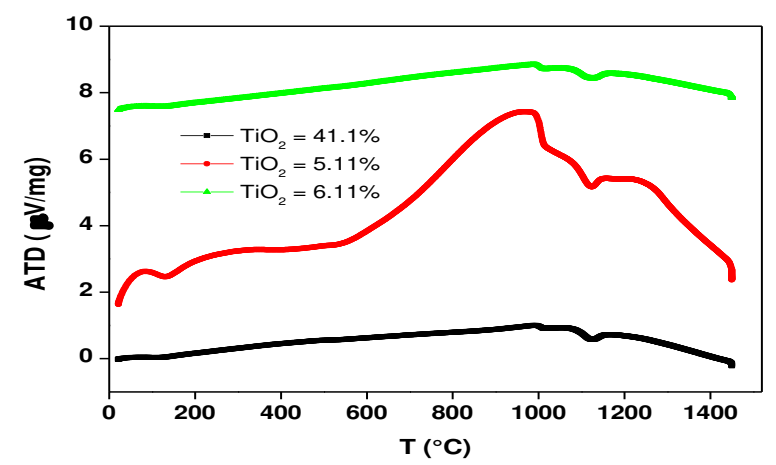

Fig. 4. DTA curve of GC materials with different $\mathrm{TiO}_{2}$ contents 
The Allotropic transformation of the different crystalline phases observed for the GC materials with different $\mathrm{TiO}_{2}$ contents is given in table 4 .

Table 4. Allotropic transformation of the different crystalline phases identified in the GCs of different $\mathrm{TiO}_{2}$ contents

\begin{tabular}{|c|c|c|c|c|}
\hline \multirow{2}{*}{ Crystalline phases } & \multicolumn{4}{|c|}{ Allotropic transformation $\left({ }^{\circ} \mathbf{C}\right)$} \\
\hline & $\mathrm{GC} 1$ & $\mathrm{GC} 2$ & GC3 & $\mathrm{GC} 4$ \\
\hline Calzirtite $\left(\mathrm{Ca}_{2} \mathrm{Zr}_{5} \mathrm{Ti}_{2} \mathrm{O}_{16}\right)$ & 999.1 & 986.1 & 997.4 & ----- \\
\hline Pyroxene $\left(\mathrm{Mg}_{0.6} \mathrm{Al}_{1.2} \mathrm{Si}_{1.8} \mathrm{O}_{6}\right)$ & 1096.3 & 1085.2 & 1083.8 & ----- \\
\hline Wollastonite $\left(\mathrm{CaSiO}_{3}\right)$ & 1142.1 & 1142.7 & 1143.1 & ----- \\
\hline
\end{tabular}

The FTIR analysis of the different GCs with different $\mathrm{TiO}_{2}$ contents gave the spectra gathered on Fig. 5. FTIR spectra of GCs with different $\mathrm{TiO}_{2}$ contents highlight an absorption band at $1427.1 \mathrm{~cm}^{-1}$ corresponding to the $\mathrm{Ba}-\mathrm{O}$ vibration [34]. In the region of the spectrum from 1100 to $1200 \mathrm{~cm}^{-1}$, the band corresponding to the presence of [ $\left.\mathrm{SiO}_{4}\right]$ tetrahedra is almost nonexistent. Si-O-Si and amorphous $\mathrm{SiO}_{2}$ bond vibrations at 1083.0, 1081.4, and $1081.7 \mathrm{~cm}^{-1}$ for GCs: GC1, GC2, and GC3, respectively. This absorption band is reported at $1080 \mathrm{~cm}^{-1}$ in pure glass [35]. The observed shift is due to compositional differences in the synthesized GCs. The characteristic band of the ring structure of $\left[\mathrm{SiO}_{4}\right]$ tetrahedra is observed at 775.2, 774.8, $776.7 \mathrm{~cm}^{-1}$, for GCs: GC1, GC2 and GC3, respectively. The latter is quoted at $775 \mathrm{~cm}^{-1}$ in the literature. This band is very weak indicating the strong ceramization of the parent glass. It also confirms the presence of Si-O-Me bonds, in a $\mathrm{Si}-\mathrm{Al}-\mathrm{Me}$ (Al, $\mathrm{Mg}$ ) base glass system [34, 36]. The Ti-O elongation vibration appears at 440,436 and $455 \mathrm{~cm}^{-1}$, for the glass ceramics: GC1, GC2 and GC3, respectively. This band appears at $455.7 \mathrm{~cm}^{-1}$ in the literature. The elongations of the Ti-O bonds characteristic of the formation of the Ti-O-Ti bridge appear in the range 493-456 $\mathrm{cm}^{-1}$ [37]. The absorption band around $405 \mathrm{~cm}^{-1}$ for GCs: GC1, GC2 and GC3, correspond to the vibration of Zr-O. This band is known to occur at $400 \mathrm{~cm}^{-1}$ [38]. It indicates the presence of calzirtite with a $\mathrm{Ca}_{2} \mathrm{Zr}_{5} \mathrm{Ti}_{2} \mathrm{O}_{16}$ skeleton in greater proportion in GC3 
(12\%) than in the other GCs. Overall, we can conclude that these spectra are representative of the complex chemical composition of the studied GCs.

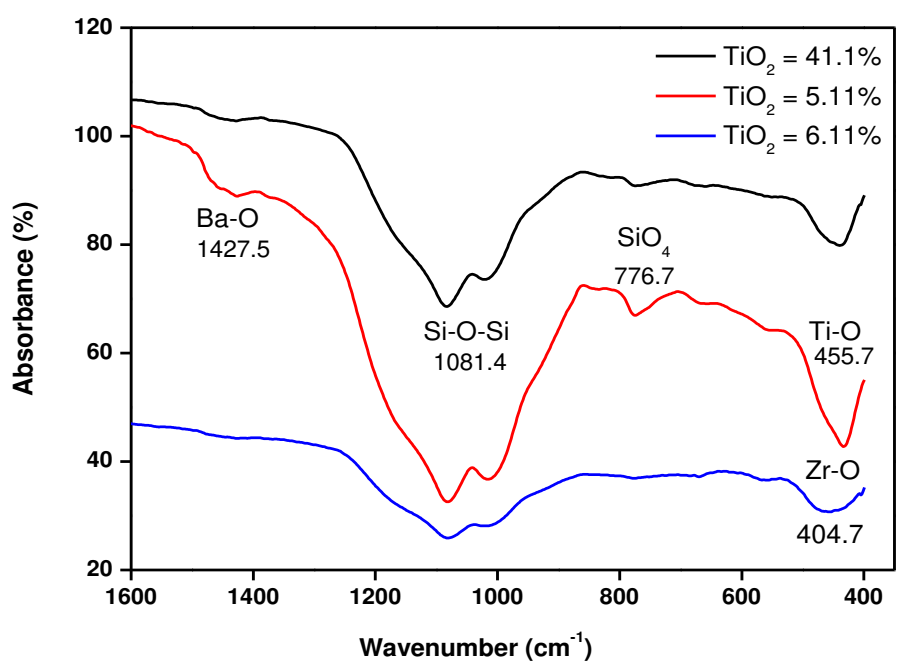

Fig. 5. FTIR spectra of the GCs with different contents of $\mathrm{TiO}_{2}$

\subsection{Chemical durability}

The variation of the elemental mass loss of $\mathrm{Si}, \mathrm{Al}, \mathrm{Mg}$ and $\mathrm{Ce}$ (actinide surrogate) elements (NL) and the elemental leaching rate of $\mathrm{Si}, \mathrm{Al}, \mathrm{Mg}$ and $\mathrm{Ce}$ elements (RLi) are calculated using the formulas (1) and (2) of section 1, respectively.

For Si and $\mathrm{Mg}$, the MCC2 test leads to a leaching equilibrium, but for different GCs at values of: $3.459310^{-5} \mathrm{~kg} / \mathrm{m}^{2}$ of Si for GC1, $11.943110^{-5} \mathrm{~kg} / \mathrm{m}^{2}$ and $14.407610^{-5} \mathrm{~kg} / \mathrm{m}^{2}$ of Mg forGC2 and GC3 respectively. For $\mathrm{Ce}$, the whole of tests lead to a steady state, except for GC2 leached in MCC1.The GC that leaches the least Ce is GC1 leached in MCC2, with 4.5837 $\mathrm{kg} / \mathrm{m}^{2}$ of Ce. For Al, NL is increasing for all $\mathrm{TiO}_{2}$ contents in GCs, whatever the employed leaching test. Therefore, $\mathrm{Al}$ is not redeposited on the GCs as a passivation layer under the present operating conditions. The best result is for GC2, leached in MCC2. We can conclude that MCC2 test is favorable for leaching unlike the MCC1 test; the high temperature is therefore a limiting factor for the release of GC elements, except for $\mathrm{Al}$, for which the concentration doesn't stabilize in the leachates at the end of test. T. Geisler et Al. [39] studied the leaching of a borosilicate glass with a composition similar to that of a German nuclear glass (54.0 $\mathrm{SiO}_{2}, 14.8 \mathrm{~B}_{2} \mathrm{O}_{3}, 2.4 \mathrm{Al}_{2} \mathrm{O}_{3}, 1.1 \mathrm{TiO}_{2}, 1.8 \mathrm{MgO}, 4.8 \mathrm{CaO}, 2.9 \mathrm{Li}_{2} \mathrm{O}, 7.2 \mathrm{Na}_{2} \mathrm{O}, 10.0$ $\left.\mathrm{CeO}_{2}\right)$ in an acidic medium $\left(1 \mathrm{M} \mathrm{HCl}\right.$, at $\left.150{ }^{\circ} \mathrm{C}\right)$. This high temperature test, compared to our results for GC1 (4.11wt.\%), leached in MCC2 shows that these values are of the same order 
of magnitude as those of the present study. They are lower than our values for Al: $8.84710^{-5}$ $\mathrm{Kg} / \mathrm{m}^{2}\left(12.478310^{-5} \mathrm{~kg} / \mathrm{m}^{2}\right)$, and higher than our values for $\mathrm{Mg}: 9.57910^{-5} \mathrm{Kg} / \mathrm{m}^{2}\left(8.862610^{-}\right.$ $\left.{ }^{5} \mathrm{Kg} / \mathrm{m}^{2}\right)$ and Ce $9.1010^{-5} \mathrm{Kg} / \mathrm{m}^{2}\left(4.583710^{-5} \mathrm{Kg} / \mathrm{m}^{2}\right)$ and $\mathrm{Si}: 0.4410^{-5} \mathrm{Kg} / \mathrm{m}^{2}\left(26.014810^{-5}\right.$ $\left.\mathrm{kg} / \mathrm{m}^{2}\right)$.

The leaching rate (RL) of $\mathrm{Si}, \mathrm{Al}, \mathrm{Mg}$ and $\mathrm{Ce}$ as a function of time, for each material doped with different contents of $\mathrm{TiO}_{2}$ are gathered on Fig. 6, for all the tests (MCC1 and MCC2). For Si, leaching equilibrium is achieved for all GCs and for both leaching tests. The leaching rate in $\mathrm{Si}$ is also negligible. The best leaching rate is $61.4710^{-9} \mathrm{Kg} / \mathrm{m}^{2} \mathrm{~d}$ in Si for GC1 leached in MCC2. This represents a GC1 mass percentage present in the leachate of $0.015 \%$. All the GCs show a stabilization of the Mg leaching rate, at the end of MCC2 test. The best $\mathrm{Mg}$ leaching rate is $191.9410^{-9} \mathrm{Kg} / \mathrm{m}^{2} \mathrm{~d}$ for GC2 leached in MCC2, which represents a GC1 Mg mass percentage present in the leachate of $0.047 \%$. This rate is negligible after 14 days of leaching. The sole GC that shows a decrease in Al leaching rate is GC1 leached in MCC2 test, which reaches $48.910^{-9} \mathrm{~kg} / \mathrm{m}^{2} \mathrm{~d}$, representing a mass content present in the leachate relative to the total amount in $\mathrm{GC} 1$ of $0.25 \%$. These results are predicted by the presence of sphene: $\mathrm{Mg}_{0.6} \mathrm{Al}_{1.2} \mathrm{Si}_{1.8} \mathrm{O}_{6}$ with a content of $77 \%$ in both $\mathrm{GC} 1$ and GC2), which constitutes a double barrier. S.Gavarini [40] reports much higher Si leaching rate values $\left(2310^{-3} \mathrm{Kg} / \mathrm{m}^{2} \mathrm{~d}\right.$ and 50 $10^{-3} \mathrm{Kg} / \mathrm{m}^{2} \mathrm{~d}$ ) for the leaching of Ce-rich glasses of chemical formula CeYSiAlO when leached in static mode at $90{ }^{\circ} \mathrm{C}$ in a closed system. For Ce, the steady state is reached for all GCs in both leaching tests, except for GC3 leached in MCC1 test. The leaching rate in Ce is also negligible. The best leaching rate is $193.710^{-9} \mathrm{Kg} / \mathrm{m}^{2} \mathrm{~d}$ in Ce for GC2 leached in MCC2; this represents a GC2 Ce mass percentage released in the leachate of $0.032 \%$, this value complies with nuclear industry requirements $\left(<10^{-3} \mathrm{Kg} \mathrm{m}^{-2} \mathrm{~d}^{-1}\right)[41,42]$. The best results are for $\mathrm{GC}$ with 4.11 and $5.11 \% \mathrm{TiO}_{2}$ for the $\mathrm{MCC} 2$ test. 

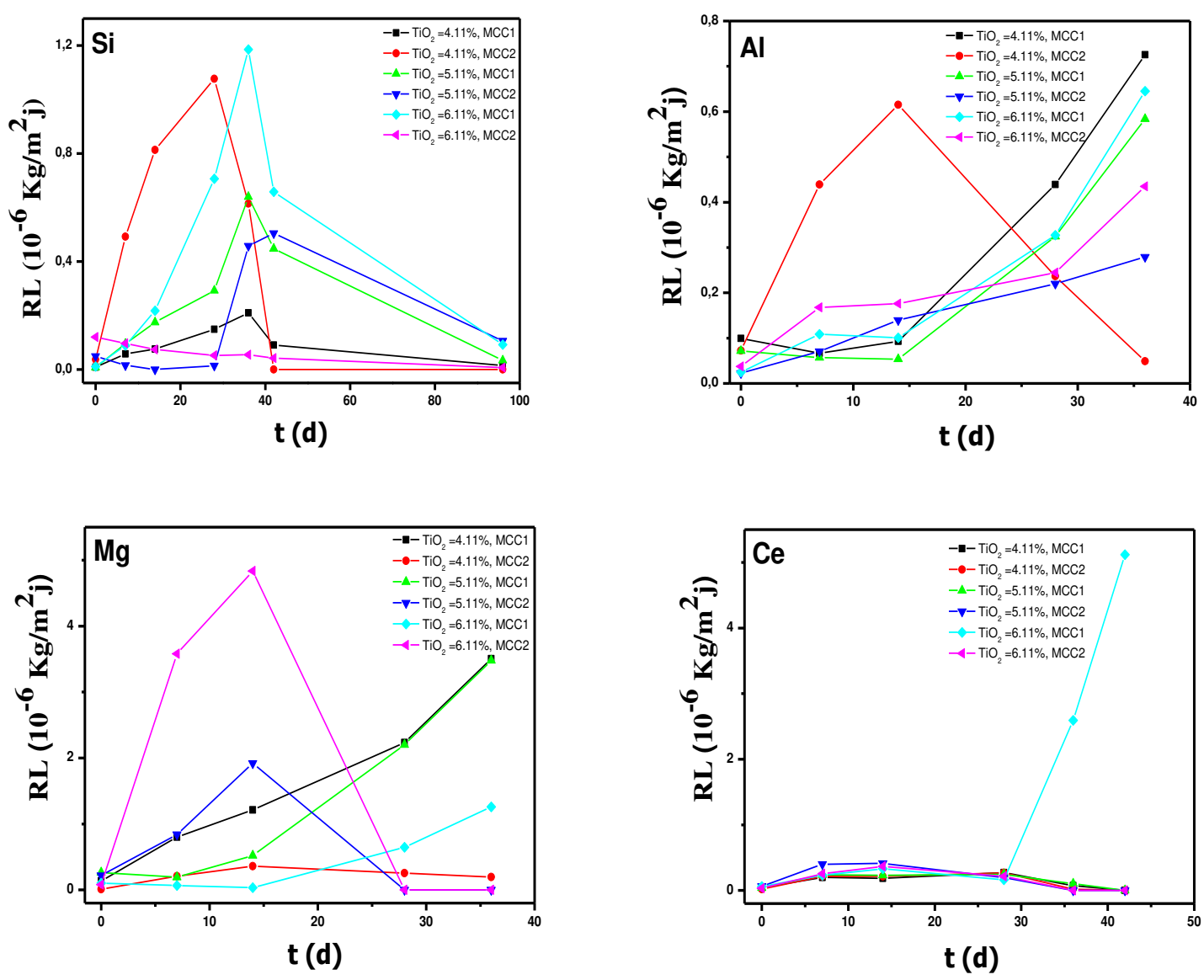

Fig. 6. Elemental leaching rates $\left(\mathrm{RL}_{\mathrm{i}}\right)$ of $\mathrm{Si}, \mathrm{Al}, \mathrm{Mg}$ and $\mathrm{Ce}$ as a function of time for the GCs with different $\mathrm{TiO}_{2}$ contents, leached in both $\mathrm{MCC} 1$ and $\mathrm{MCC} 2$ tests

\section{Conclusion}

In this study, we performed the synthesis and characterization of glass-ceramic matrices, based on an aluminosilicate glass, in the system $\mathrm{SiO}_{2}-\mathrm{Al}_{2} \mathrm{O}_{3}-\mathrm{CaO}-\mathrm{MgO}-\mathrm{ZrO}_{2}-\mathrm{TiO}_{2}$, with four contents of $\mathrm{TiO}_{2}$, ranging from 4.11 to 7.11 wt.\%. These $\mathrm{GC}$ confinement matrices are intended to confine in their structure both fission products and lanthanides elements, from radioactive waste. The GC synthesis is carried out in several stages: a double fusion of the oxides mixture at $1350{ }^{\circ} \mathrm{C}$, a nucleation at $564{ }^{\circ} \mathrm{C}$, and a crystal growth at $1010{ }^{\circ} \mathrm{C}$. The GC synthesis of the material with $7.11 \mathrm{wt} . \% \mathrm{TiO}_{2}$ content, was not successful. For the others materials, the obtained GC have Archimedes densities in the range of $2.891-2.962 \mathrm{~g} / \mathrm{cm}^{3}$. Except for the GC with 7.11 wt.\% $\mathrm{TiO}_{2}$, the XRD phase identification show that the main formed phases in the materials are pyroxene, powelite and calzirtite phases, which are known as self-irradiation resistant phases. The SEM confirmed the morphological aspect of these phases in the microstructures. The DTA analysis reveals the allotropic transformations of such 
phases. The FTIR analysis spectra are representative of the complex chemical composition of the studied glass-ceramics.MCC1 and MCC2 tests, performed on selected glass ceramic materials among the different $\mathrm{TiO}_{2}$ contents GCs, indicate that the materials with 4.11 and 5.11 wt. $\% \mathrm{TiO}_{2}$ have the best leaching behavior, for $\mathrm{MCC} 2$ test $\left(90^{\circ} \mathrm{C}\right)$, for the four analyzed elements( $\mathrm{Si}, \mathrm{Al}, \mathrm{Mg}$ and $\mathrm{Ce})$.The leaching rate in $\mathrm{Ce}$ (actinide surrogate) is negligible. The best leaching rate is $193.710^{-9} \mathrm{Kg} / \mathrm{m}^{2} \mathrm{~d}$ after 28 leaching days in Ce for $5.11 \mathrm{wt} \%$ leached in MCC2. The studied GCs with different $\mathrm{TiO}_{2}$ contents may potentially be candidate matrix for the disposal of high-level waste.

\section{Declarations}

Conflict of interest The authors declare that they have no conflict of interest.

\section{References}

[1] J. Hiet, Motifs structuraux dans des verres modèles pour le stockage des actinides, Université d'Orléans 2009.

[2] P.J. Hayward, The use of glass ceramics for immobilising high level wastes from nuclear fuel recycling, Glass Technology, 29 (1988) 122-136.

[3] W. Lutze, R.C. Ewing, Radioactive waste forms for the future, Elsevier Science Pub B. V Amsterdam, 1988.

[4] I. Donald, B. Metcalfe, R.J. Taylor, The immobilization of high level radioactive wastes using ceramics and glasses, J. Mater. Sci 32 (1997) 5851-5887. https://doi.org/10.1023/A:1018646507438.

[5] W. Lee, M. Ojovan, M. Stennett, N. Hyatt, Immobilisation of radioactive waste in glasses, glass composite materials and ceramics, Adv. Appl. Ceram, 105 (2006) 3-12. https://doi.org/10.1179/174367606X81669.

[6] A. Ringwood, S. Kesson, K. Reeve, D. Levins, E. Ramm, Synroc.. In: Lutze W, Ewing RC, North-Holland, Amsterdam 1988.

[7] M.-S. Paizullakhanov, I. Atabaev, S. Faiziev, The glass ceramics pyroxene composition synthesized on the solar furnace, Int.J.Mining.Sci 2(2016) 8-12. http://dx.doi.org/10.20431/2454-9460.0202002 
[8] W. Höland, G. Beall, Principles of designing glass-ceramic formation,Glass-ceramic technology, 2019. https://doi.org/10.1002/9781119423737.ch1.

[9] E. Maddrell, S. Thornber, N.C. Hyatt, The influence of glass composition on crystalline phase stability in glass-ceramic wasteforms, J. Nucl.Mater 456 (2015) 461-466. https://doi.org/10.1016/j.jnucmat.2014.10.010

[10] H. Khedim, H. Nonnet, F.O. Méar, Development and characterization of glass-ceramic sealants in the $\left(\mathrm{CaO}-\mathrm{Al}_{2} \mathrm{O}_{3}-\mathrm{SiO}_{2}-\mathrm{B}_{2} \mathrm{O}_{3}\right)$ system for solid oxide electrolyzer cells, J.Power Sources, 216 (2012) 227-236. https://doi.org/10.1016/j.jpowsour.2012.05.041.

[11] P. Loiseau, D. Caurant, O. Majerus, N. Baffier, C. Fillet, Competition Between Internal and Surface Crystallization in Glass-ceramics Developed for Actinides Immobilization, MRS Online Proc. Libr, 807 (2003) 333-338. https://doi.org/10.1557/PROC-807-333.

[12] M.V. Alencar, G.V. Bezerra, L.D. Silva, J.F. Schneider, M.J. Pascual, A.A. Cabral, Structure, Glass Stability and Crystallization Activation Energy of SrO-CaO-B2O3-SiO2 glasses doped with $\mathrm{TiO}_{2}$, J.Non-Cryst. Solids, $554 \quad$ (2021) 120-605. https://doi.org/10.1016/j.jnoncrysol.2020.120605.

[13] S. Salama, E.A. Saad, H. Darwish, H. Abo-Mosallam, Formation of glass-ceramic materials based on pyroxene solid solution-fluorapatite phases and their thermal expansion properties, Ceram. Int, 31 (2005) 559-566. https://doi.org/10.1016/j.ceramint.2004.07.004.

[14] M. Lu, F. Wang, Q. Liao, K. Chen, J. Qin, S. Pan, FTIR spectra and thermal properties of TiO2-doped iron phosphate glasses, J. Mol. Struct, 1081 (2015) 187-192. https://doi.org/10.1016/j.molstruc.2014.10.029.

[15] X. Liu, J. Zhou, S. Zhou, Y. Yue, J. Qiu, Transparent glass-ceramics functionalized by dispersed crystals, Prog. Mater. Sci, $97 \quad$ (2018) 38-96. https://doi.org/10.1016/j.pmatsci.2018.02.006.

[16] F. Wang, M. Lu, Q. Liao, Y. Wang, H. Zhu, G. Xiang, L. Li, Y. Zhu, Titanium-doped iron phosphate based glass ceramic waste forms containing $50 \mathrm{wt} \%$ simulated nuclear waste, $\begin{array}{lllll}\text { Mater.Chem. } & \text { and } & \text { Phys, } & 239 & \text { (2020) }\end{array}$ https://doi.org/10.1016/j.matchemphys.2019.122314.

[17] D.M. Nour-el-Hayet Kamel, Z. Kamel, A. Djeridi, S. Mouhamou, A. Benmounah, R. Souag, M. Taouinet, H. Ait-Amar, Effect of the Ce Content on a Nuclear Waste Glassy 
Matrix in the System $\mathrm{SiO}_{2}-\mathrm{Al}_{2} \mathrm{O}_{3}-\mathrm{CaO}-\mathrm{MgO}-\mathrm{ZrO}_{2}-\mathrm{TiO}_{2}$, Synthesized at a Low Melting Temperature, J.Mater.Sci and Eng A, 3 (2013) 209-223.

[18] R. Souag, N. Kamel, Y. Mouheb, M. Hammadi, Z. Kamel, D. Moudir, F. Aouchich, S. Kamariz, Study of the effect of $\mathrm{Ca} / \mathrm{Mg}$ alkali-oxides ratio on the structure of a glass-ceramic based on an aluminosilicated glass containing $2 \mathrm{wt} . \%$ of zirconolite crystalline phase, Sci.Sinter, 46 (2014) 377-383. https://doi.org/10.2298/SOS1403377S.

[19] P. JCPDS, Diffraction Data CD-ROM, International Center for Diffraction Data, Newtown Square, PA, (2004).

[20] Omnic, Nicolet instrument, 1992-2001.

[21] M.I. Ojovan, W.E. Lee, Glassy wasteforms for nuclear waste immobilization, Metall. Mater. Trans A, 42 (2011) 837-851. https://doi.org/10.1007/s11661-010-0525-7.

[22] I.W. Donald, Waste immobilization in glass and ceramic based hosts: radioactive, toxic and hazardous wastes, John Wiley \& Sons2010.

[23] D.C. A. Quintas, O. Majérus, Effect of changing the rare earth cation type onthe structure and crystallisation behaviour of an aluminoborosilicate glass, Proc. XXI Int. Congr. GlassStrasbourg, France, 1-7 July 2007.

[24] T. Wakihara, J. Tatami, K. Komeya, T. Meguro, A. Kidari, S. Hampshire, M.J. Pomeroy, Effect of $\mathrm{TiO}_{2}$ addition on thermal and mechanical properties of $\mathrm{Y}-\mathrm{Si}-\mathrm{Al}-\mathrm{O}-\mathrm{N}$ glasses, $\mathrm{J}$. $\begin{array}{lllll}\text { Eur. } & \text { Ceram.Society, } & 32 & \text { (2012) }\end{array}$ https://doi.org/10.1016/j.jeurceramsoc.2011.12.002.

[25] F. Wang, L. Guo, C. Wang, F. Ye, Calcium-magnesium-alumina-silicate (CMAS) resistance characteristics of LnPO4 $(\mathrm{Ln}=\mathrm{Nd}, \mathrm{Sm}, \mathrm{Gd})$ thermal barrier oxides, J.Eur. Ceram. Society, 37 (2017) 289-296. https://doi.org/10.1016/j.jeurceramsoc.2016.08.013.

[26] I. Bardez, P. Loiseau, D. Caurant, N. Baffier, C. Fillet, Etude de céramiques et de vitrocéramiques à base de zirconolite-Hf $\left(\mathrm{CaHfTi}_{2} \mathrm{O}_{7}\right)$ destinées au confinement de déchets nucléaires de haute activité, Etude de céramiques et de vitrocéramiques à base de zirconoliteHf $\left(\mathrm{CaHfTi}_{2} \mathrm{O}_{7}\right)$ destinées au confinement de déchets nucléaires de haute activité, 2002.

[27] H. Rossell, Solid solution of metal oxides in the zirconolite phase CaZrTi2O7. II: The ternary phase $\mathrm{CaZr}_{\mathrm{x}} \mathrm{Ti}_{3}-\mathrm{xO}_{7}$, J.of Solid State Chem, 99 (1992) 52-57. https://doi.org/10.1016/0022-4596(92)90287-6. 
[28] Y.-H. Wu, K.-C. Hsu, C.-H. Lee, Effects of $\mathrm{B}_{2} \mathrm{O}_{3}$ and $\mathrm{P}_{2} \mathrm{O}_{5}$ doping on the microstructure evolution and mechanical strength in a lithium aluminosilicate glass-ceramic material with $\mathrm{TiO}_{2}$ and $\mathrm{ZrO}_{2}$, Ceram. Int, 38 (2012) 4111-4121. https://doi.org/10.1016/j.ceramint.2012.01.069.

[29] L. Bozadzhiev, G. Georgiev, R. Bozadzhiev, A glass-ceramic material for fixation of radioactive waste, Sci. Sinter, 43 (2011) 225-229. https://doi.org/10.2298/SOS1102225B.

[30] M. Chavoutier, D. Caurant, O. Majérus, R. Boulesteix, P. Loiseau, C. Jousseaume, E. Brunet, E. Lecomte, Effect of $\mathrm{TiO}_{2}$ content on the crystallization and the color of $\left(\mathrm{ZrO}_{2}\right.$, $\mathrm{TiO}_{2}$ )-doped $\mathrm{Li}_{2} \mathrm{O}-\mathrm{Al}_{2} \mathrm{O}_{3}-\mathrm{SiO}_{2} \quad$ glasses, J.Non-cryst. $\quad$ solids, 384 (2014) 15-24. https://doi.org/10.1016/j.jnoncrysol.2013.03.034.

[31] P. Alizadeh, V. Marghussian, Effect of nucleating agents on the crystallization behaviour and microstructure of $\mathrm{SiO}_{2}-\mathrm{CaO}-\mathrm{MgO}\left(\mathrm{Na}_{2} \mathrm{O}\right)$ glass-ceramics, J.Eur.Ceram. Society, 20 (2000) 775-782. https://doi.org/10.1016/S0955-2219(99)00136-3.

[32] D. Caurant, O. Majerus, E. Fadel, M. Lenoir, C. Gervais, O. Pinet, Effect of molybdenum on the structure and on the crystallization of $\mathrm{SiO}_{2}-\mathrm{Na}_{2} \mathrm{O}-\mathrm{CaO}-\mathrm{B} 2 \mathrm{O}_{3}$ glasses, J. Am. Ceram.Soc, 90 (2007) 774-783. https://doi.org/10.1111/j.1551-2916.2006.01467.x.

[33] M.-L. Pascal, A. Di Muro, M. Fonteilles, C. Principe, Zirconolite and calzirtite in banded forsterite-spinel-calcite skarn ejecta from the 1631 eruption of Vesuvius: inferences for magma-wallrock interactions, Mineral.Mag, $73 \quad$ (2009) 333-356. https://doi.org/10.1180/minmag.2009.073.2.333.

[34] M. Sales, J. Alarcon, Crystallization of sol-gel derived glass ceramic powders in the $\mathrm{CaO}-\mathrm{MgO}-\mathrm{Al}_{2} \quad \mathrm{O}_{3}-\mathrm{SiO}_{2} \quad$ system, J. $\quad$ Mater. $\quad$ Sci, $30 \quad$ (1995) 2341-2347. https://doi.org/10.1007/BF01184584.

[35] N. Nagai, H. Hashimoto, FT-IR-ATR study of depth profile of $\mathrm{SiO}_{2}$ ultra-thin films, Appl. Surf. Sci, 172 (2001) 307-311. https://doi.org/10.1016/S0169-4332(00)00867-9.

[36] R. Petrović, D. Janaćković, S. Zec, S. Drmanić, L. Kostić-Gvozdenović, Crystallization behavior of alkoxy-derived cordierite gels, J. Sol-gel Sci.Technol, 28 (2003) 111-118. https://doi.org/10.1023/A:1025649406466.

[37] T. Bezrodna, G. Puchkovska, V. Shymanovska, J. Baran, H. Ratajczak, IR-analysis of Hbonded $\mathrm{H} 2 \mathrm{O}$ on the pure $\mathrm{TiO}_{2}$ surface, J.Mol. Struct, 700 (2004) 175-181. https://doi.org/10.1016/j.molstruc.2003.12.057. 
[38] I.H. Joe, A.K. Vasudevan, G. Aruldhas, A. Damodaran, K. Warrier, FTIR as a tool to study high-temperature phase formation in sol-gel aluminium titanate, J.Solid State Chem, 131 (1997) 181-184. https://doi.org/10.1006/jssc.1997.7371.

[39] T. Geisler, A. Janssen, D. Scheiter, T. Stephan, J. Berndt, A. Putnis, Aqueous corrosion of borosilicate glass under acidic conditions: a new corrosion mechanism, J.Non-Cryst. Solids, 356 (2010) 1458-1465. https://doi.org/10.1016/j.jnoncrysol.2010.04.033.

[40] S. Gavarini, Durabilité chimique et comportement à l'irradiation des verres quaternaires LnYSiAlO (Ln= La ou Ce), Université d'Orléans, 2002.

[41] L. Wu, H. Li, X. Wang, J. Xiao, Y. Teng, Y. Li, Effects of Nd content on structure and chemical durability of zirconolite-barium borosilicate glass-ceramics, J. Am. Ceram. Soc, 99 (2016) 4093-4099.https://doi.org/10.1111/jace.14440.

[42] EJ 1186-2005, Characterization of Radioactive Waste Forms and Packages, Nuclear Industry Standard in China, Commission for Science, Technology and Industry for National Defense, Beijing, China, 2005 